Available online at GSC Online Press Directory

GSC Biological and Pharmaceutical Sciences

e-ISSN: 2581-3250, CODEN (USA): GBPSC2

Journal homepage: https://www.gsconlinepress.com/journals/gscbps

(RESEARCH ARTICLE)

\title{
Microbial quality of locally processed suya sold in Owerri metropolis, Imo State, Nigeria.
}

\author{
Christian Chukwuemeka Ike ${ }^{1,{ }^{*}}$ and Happiness Odinakachi Ogwuegbu ${ }^{2}$ \\ ${ }^{1}$ Department of Biological Sciences (Microbiology Programme), College of Basic and Applied Sciences, Rhema University, \\ Nigeria, P.M.B. 7021 Aba, Abia State. \\ ${ }^{2}$ Department of Microbiology, Abia State University Uturu, P.M.B. 2000 Uturu, Abia State, Nigeria.
}

Publication history: Received on 13July 2020; revised on 06 September 2020; accepted on 09 September 2020

Article DOI: https://doi.org/10.30574/gscbps.2020.12.3.0221

\begin{abstract}
Microbial quality of locally prepared suya sold in Owerri metropolis was analyzed using standard microbiological methods. A total of fifty (50) samples randomly drawn from five (5) different locations were analyzed. The mean heterotrophic count of processed suya ranged from $1.0 \times 10^{2} \pm 0.33$ to $3.4 \times 10^{3} \pm 0.31 \mathrm{CFU} / \mathrm{g}$, mean coliform count of processed suya ranged from $0.5 \times 10^{1} \pm 0.13$ to $1.5 \times 10^{2} \pm 0.10 \mathrm{CFU} / \mathrm{g}$, while mean fungal count of processed suya ranged from $3.9 \times 10^{1} \pm 0.08$ to $1.3 \times 10^{3} \pm 0.14 \mathrm{CFU} / \mathrm{g}$. Seven (7) bacterial isolates were identified to include Bacillus species, Escherichia coli, Salmonella species, Staphylococcus aureus, Shigella species, Klebsiella species, Pseudomonas species and three (3) fungal isolates were identified to include Candida albicans, Penicillium species and Aspergillus species. From the results, it is clearly evident that handling and processing activities of suya in Owerri metropolis were poor and below acceptable hygiene standards. In order to achieve a sustainable food safety quality for vended suya across the different locations in Owerri metropolis, there is need for education and awareness campaigns for processors, vendors and consumers on the role of personal hygiene in food safety and the imminent risk of consuming contaminated suya.
\end{abstract}

Keywords: Suya; Suya sauce; Beef; Vegetable oil; Hygiene practices

\section{Introduction}

Meat has exerted a crucial role in human evolution and is an important component of a healthy and balanced diet due to its nutritional richness. The increase in population with consequent pressing demand for enhanced requirements of food has led to a continued search for novel sources of food and protein. Meat is an animal flesh that is eaten as food and excellent source of protein in human diet. It is highly susceptible to microbial contaminations, which can cause its spoilage and food borne infections in human, resulting in economic and health losses [1]. Meat is one of the most perishable foods and its composition is ideal with abundance of all nutrients required for the growth of a wide range of spoilage bacteria, yeasts and molds [2; 3]. Potential for microbial contamination is influenced by the condition prior to slaughter, abattoir practices, extent of handling and subsequent storage conditions [4].

Processed meat is any meat which has been modified in order to either improve its taste or extend its shelf life. Some methods of meat processing include salting, smoking, curing, and fermentation. Processed meat is usually composed of pork, beef, and sometimes poultry [3]. This leads to production of ready-to-eat beef products such as suya, kilishi, balangu and kundi as popular street foods. Suya is a spicy, traditionally processed stick meat product that has its origin from the Northern part of Nigeria and is commonly prepared by the Hausas from beef [5]. Suya is prepared basically from boneless meat of animals [6] and is however the most popular with its consumption extended to other parts of the

${ }^{*}$ Corresponding author: Ike Christian Chukwuemeka

Department of Biological Sciences (Microbiology Programme), College of Basic and Applied Sciences, Rhema University, Nigeria, P.M.B. 7021 Aba, Abia State. 
country [7]. In big cities and small towns, suya vendors have become very prominent with their grill stands becoming very busy from about midday until late at night. It is gradually making its way into elite circles where it has become a delicacy served at parties [8]. Suya as a popular, traditionally processed, ready to eat Nigerian meat product may be served or sold along the streets, in club houses, at picnics, parties, restaurants and within institutions [9]. It is a consumer fast food and its preparation and sales along the streets are usually done under unhygienic conditions because they are still done locally with crude tools [10] and the risk of contamination is very high.

Within the meat industry, assurance of meat safety and quality are of paramount importance. The presence of pathogens in the food supply in low numbers is undesirable and is considered a major cause of gastrointestinal disease world-wide [11]. Traditional approaches to meat safety and quality have relied heavily on regulatory inspection and sampling regimes. Animal tissues under the hides (skin) of healthy cattle are usually sterile. Consequently, tissues become contaminated during the slaughtering process. Although, muscles of healthy animals do not contain microorganisms. Meat tissues get contamination during the various stages of slaughter and transportation [12;13]. The health status of animals prior to slaughtering and prevailing circumstances in the slaughter house contributes to the quality of meat from such animals [14].

Because of the high rate of consumption of suya, there is need for microbiological analyses of the suya products so as to evaluate the food safety level of the product in order to avert food borne infections related with its consumption. Suya indeed constitutes a food safety risk [7; 15], and since meat have been considered as highly nutritious and rich in proteins, it could serve as a good substrate for microbial growth [16]. Therefore, this work is aimed at determining the microbial quality of locally prepared suya sold in Owerri metropolis, Imo State, Nigeria.

\section{Material and methods}

\subsection{Processing of suya}

The beef was cut into very thin fillets. This thin fillet of beef after processing is called suya as referred to in this work. The suya skewers (sticks) were soaked in cold water for at least 5 hours to ensure the sticks do not burn during the roasting of the suya. The fillets of beef were threaded on the suya sticks. Some quantity of vegetable oil was poured into a bowl, small quantity of salt was added and stirred. A cooking brush was used to rub the vegetable oil on the threaded fillets to enable the suya sauce stick firmly on the fillets. A wide dish was used to suspend the threaded fillets, while the suya sauce was spread and dab on the fillets so that the beef could take up as much of the spice as possible until all the beef is covered. The spiced beef was kept in a flat tray, covered and allowed to marinate for one (1) hour. The marinated spiced beef were placed flat on a rack, on a heating/ temperature regulated oven $\left(130-150{ }^{\circ} \mathrm{C}\right)$, barbeque stove, or locally constructed roaster and allowed to roast. After 15 - 20 minutes, the suya were flipped to roast the underside with a total roasting time of about 30 - 40 minutes, which is dependent upon the thickness of the fillets.

\subsection{Processing of suya sauce}

Yaji is a complex seasoning comprising of groundnut cake powder, additives and spices [17]. The seasoning additives include table salt and monosodium glutamate while spices include ginger, cloves (garlic), red pepper, and black pepper. The suya sauce was processed by adding and mixing the ground ingredients (seasoning additives and spices) one after the other into the groundnut cake powder in accurate proportions to taste.

\subsection{Study area}

The study area is Owerri, Imo State, Nigeria. The geographical coordinates are latitude $5.4836^{\circ} \mathrm{N}$ and longitude 7.0332 ${ }^{\circ} \mathrm{E}$. The area is of tropical climatic conditions with rain forest features. The soil type is silt-clay and the weather is typical of rain forest, with average annual temperature ranging between $25-35^{\circ} \mathrm{C}$ as lowest and highest values, respectively.

\subsection{Collection of sample}

A total of fifty (50) samples of locally processed suya were bought at random from five different locations in Owerri metropolis. Random samples of different locally processed suya were aseptically collected with sterile ziploc bags. Samples were transported in ice bags to Microbiology Laboratory, Rhema University, Nigeria for analysis.

\subsection{Microbiological analysis of samples}

Ten fold serial dilutions of suya samples were done using sterile peptone water as diluent. One gramme ( $1 \mathrm{~g})$ each of the samples was aseptically cut using forceps and sterile scissors and transferred into a sterile test tube containing nine milliliter $(9 \mathrm{~mL})$ of sterile peptone water, stirred with sterile glass rod and shaken vigorously to ensure adequate 
disengagement of microorganisms to obtain $10^{-1}$ dilution. Serial dilutions of the homogenates were continued and made step-wisely till the fifth (5th) tube, to obtain dilutions of $10^{-2}$ to $10^{-5}$. Spread plate techniques of [18] were used to enumerate bacteria and fungi in the samples and each dilution was plated in replicates using plate count agar for mean heterotrophic count, tergitol agar for mean coliform count, and fortified sabouraud dextrose agar (SDA) for mean fungal count. The plates were incubated at $35 \pm 2{ }^{\circ} \mathrm{C}$ for 72 hours and 24 hours for mean heterotrophic and coliform counts respectively and $25 \pm 2{ }^{\circ} \mathrm{C}$ for 120 hours for mean fungal counts. Pure bacterial isolates were identified using cultural, morphological and biochemical characterization. Identification of the bacteria to genera level was based on the schemes of [19]. The purified fungal isolates were identified on the basis of macroscopic and microscopic characteristics by slide culture technique and lactophenol staining. The scheme of [20] was used for the identification.

\subsection{Statistical analyses}

All obtained data in this study were analyzed using analysis of variance (ANOVA). Descriptive statistics in form of mean, standard deviation, and Duncan post hoc were also used to assess the data, and analyses were done using SPSS version 20 (Statistical Product and Service Solutions).

\section{Results}

The microbial qualities of locally processed suya are presented in Tales 1, 2 and 3. The bacterial counts including mean heterotrophic and coliform counts are shown in Table 1and 2 respectively, while that of fungal count is shown in Table 3. Mean heterotrophic count of processed suya ranged from $1.0 \times 10^{2} \pm 0.33$ to $3.4 \times 10^{3} \pm 0.31 \mathrm{CFU} / \mathrm{g}$, mean coliform count of processed suya ranged from $0.5 \times 10^{1} \pm 0.13$ to $1.5 \times 10^{2} \pm 0.10 \mathrm{CFU} / \mathrm{g}$ while mean fungal count of processed suya ranged from $3.9 \times 10^{1} \pm 0.08$ to $1.3 \times 10^{3} \pm 0.14 \mathrm{CFU} / \mathrm{g}$. In overall assessment, samples of suya from Control-Round-About had highest counts, while the least counts were with samples of suya from New Owerri-Concord/ All Season Hotels location. All values obtained in this study were statistically significant when compared $(\mathrm{p}<0.05)$.

Table 1 Mean heterotrophic count

\begin{tabular}{|c|c|c|c|c|c|}
\hline \multirow{2}{*}{$\begin{array}{l}\text { Suya } \\
\text { samples }\end{array}$} & \multirow[b]{2}{*}{$\begin{array}{l}\text { IMSU Junction } \\
\text { (CFU/g) }\end{array}$} & \multicolumn{2}{|c|}{ Sample Locations } & \multirow[b]{2}{*}{$\begin{array}{l}\text { Fire Service } \\
\text { Round About } \\
\text { (CFU/g) }\end{array}$} & \multirow[b]{2}{*}{$\begin{array}{l}\text { New Owerri- } \\
\text { Concord/All } \\
\text { Season Hotels } \\
(\mathrm{CFU} / \mathrm{g})\end{array}$} \\
\hline & & $\begin{array}{l}\text { Standard Shoe } \\
\text { Junction } \\
\text { (CFU/g) }\end{array}$ & $\begin{array}{l}\text { Control-Round- } \\
\text { About } \\
\text { (CFU/g) }\end{array}$ & & \\
\hline $\mathrm{S}_{1}$ & $2.5 \times 10^{3} \pm 0.15^{b}$ & $3.0 \times 10^{2} \pm 0.10^{\mathrm{d}}$ & $2.8 \times 10^{3} \pm 0.11^{\mathrm{a}}$ & $2.3 \times 10^{3} \pm 0.07^{c}$ & $2.3 \times 10^{2} \pm 0.15^{\mathrm{e}}$ \\
\hline $\mathrm{S}_{2}$ & $6.1 \times 10^{2} \pm 0.37 c$ & $2.1 \times 10^{3} \pm 0.17^{b}$ & $3.4 \times 10^{3} \pm 0.31^{\mathrm{a}}$ & $4.5 \times 10^{2} \pm 0.55^{d}$ & $4.4 \times 10^{2} \pm 0.82^{\mathrm{de}}$ \\
\hline $\mathrm{S}_{3}$ & $2.4 \times 10^{2} \pm 0.15^{c}$ & $2.2 \times 10^{2} \pm 0.09^{c d}$ & $2.0 \times 10^{3} \pm 0.27^{b}$ & $2.0 \times 10^{3} \pm 0.09 \mathrm{~b}$ & $2.3 \times 10^{3} \pm 0.61^{\mathrm{a}}$ \\
\hline $\mathrm{S}_{4}$ & $1.5 \times 10^{3} \pm 0.26^{\mathrm{ab}}$ & $1.3 \times 10^{2} \pm 0.14^{\mathrm{cd}}$ & $1.6 \times 10^{3} \pm 0.05^{a}$ & $1.4 \times 10^{2} \pm 0.14^{c}$ & $1.0 \times 10^{2} \pm 0.33^{\mathrm{e}}$ \\
\hline $\mathrm{S}_{5}$ & $3.0 \times 10^{2} \pm 0.14^{\mathrm{b}}$ & $1.8 \times 10^{2} \pm 0.23^{\mathrm{cd}}$ & $2.0 \times 10^{2} \pm 0.32^{c}$ & $1.6 \times 10^{2} \pm 0.33^{\mathrm{d}}$ & $1.4 \times 10^{3} \pm 0.18^{a}$ \\
\hline $\mathrm{S}_{6}$ & $3.3 \times 10^{3} \pm 0.23^{a}$ & $2.9 \times 10^{3} \pm 0.51^{b}$ & $2.7 \times 10^{3} \pm 0.28 \mathrm{bc}$ & $2.3 \times 10^{3} \pm 0.42^{\mathrm{d}}$ & $2.6 \times 10^{3} \pm 0.31^{c}$ \\
\hline $\mathrm{S}_{7}$ & $6.1 \times 10^{2} \pm 0.18^{c}$ & $3.5 \times 10^{3} \pm 0.05^{\mathrm{a}}$ & $2.5 \times 10^{3} \pm 0.31^{b}$ & $4.5 \times 10^{2} \pm 0.77^{d}$ & $4.2 \times 10^{2} \pm 0.37 \mathrm{e}$ \\
\hline $\mathrm{S}_{8}$ & $2.4 \times 10^{3} \pm 0.46^{\mathrm{a}}$ & $2.2 \times 10^{3} \pm 0.18^{\mathrm{ab}}$ & $2.0 \times 10^{3} \pm 0.45^{\mathrm{bc}}$ & $2.0 \times 10^{3} \pm 0.55^{b c}$ & $1.8 \times 10^{3} \pm 0.44^{c}$ \\
\hline $\mathrm{S}_{9}$ & $1.5 \times 10^{3} \pm 0.09^{a}$ & $1.3 \times 10^{2} \pm 0.91^{\mathrm{cd}}$ & $1.6 \times 10^{2} \pm 0.76^{b c}$ & $1.4 \times 10^{2} \pm 0.97 \mathrm{c}$ & $1.8 \times 10^{2} \pm 0.86^{b}$ \\
\hline $\mathrm{S}_{10}$ & $2.7 \times 10^{3} \pm 0.20^{\mathrm{a}}$ & $1.8 \times 10^{3} \pm 0.84^{\mathrm{bc}}$ & $2.0 \times 10^{3} \pm 0.66^{b}$ & $1.6 \times 10^{3} \pm 0.81^{c}$ & $2.2 \times 10^{2} \pm 0.06^{d}$ \\
\hline
\end{tabular}

Within rows, values followed by the same alphabets are not significantly different but those followed by different alphabets are significantly different $(p<0.05)$. Recommended Standard Counts: Aerobic bacteria count $(\mathrm{ABC})=\leq 10^{5} / \mathrm{g}$, Coliform count $(\mathrm{CC})=<100 / \mathrm{g}$, Fungal count $(\mathrm{FC})=\leq$ $104 / g[21 ; 22]$. 
Table 2 Mean coliform count

\begin{tabular}{llllll}
\hline $\begin{array}{l}\text { Suya } \\
\text { Samples }\end{array}$ & $\begin{array}{l}\text { IMSU Junction } \\
\text { (CFU/g) }\end{array}$ & $\begin{array}{l}\text { Standard Shoe } \\
\text { Junction } \\
\text { (CFU/g) }\end{array}$ & $\begin{array}{l}\text { Control-Round- } \\
\text { About } \\
\text { (CFU/g) }\end{array}$ & $\begin{array}{l}\text { Fire Service } \\
\text { Round About } \\
\text { (CFU/g) }\end{array}$ & $\begin{array}{l}\text { New Owerri - } \\
\text { Concord/ All } \\
\text { Seasons Hotels } \\
\text { (CFU/g) }\end{array}$ \\
\hline$S_{1}$ & $0.5 \times 10^{2} \pm 0.50^{\mathrm{c}}$ & $1.2 \times 10^{2} \pm 0.03^{\mathrm{a}}$ & $0.7 \times 10^{2} \pm 0.37^{\mathrm{b}}$ & $2.8 \times 10^{1} \pm 0.01^{\mathrm{d}}$ & $1.1 \times 10^{1} \pm 0.88^{\mathrm{e}}$ \\
$\mathrm{S}_{2}$ & $1.8 \times 10^{1} \pm 0.19^{\mathrm{d}}$ & $1.0 \times 10^{2} \pm 0.04^{\mathrm{b}}$ & $1.1 \times 10^{2} \pm 0.22^{\mathrm{b}}$ & $2.4 \times 10^{1} \pm 0.25^{\mathrm{c}}$ & $1.4 \times 10^{2} \pm 0.06^{\mathrm{a}}$ \\
$\mathrm{S}_{3}$ & $0.9 \times 10^{2} \pm 0.10^{\mathrm{c}}$ & $2.3 \times 10^{1} \pm 0.16^{\mathrm{d}}$ & $1.4 \times 10^{2} \pm 0.56^{\mathrm{a}}$ & $1.2 \times 10^{2} \pm 0.33^{\mathrm{ab}}$ & $0.5 \times 10^{1} \pm 0.13^{\mathrm{e}}$ \\
$\mathrm{S}_{4}$ & $1.1 \times 10^{2} \pm 0.39^{\mathrm{bc}}$ & $3.8 \times 10^{1} \pm 0.32^{\mathrm{d}}$ & $1.4 \times 10^{2} \pm 0.55^{\mathrm{a}}$ & $1.5 \times 10^{1} \pm 0.49^{\mathrm{e}}$ & $1.3 \times 10^{2} \pm 0.45^{\mathrm{ab}}$ \\
$\mathrm{S}_{5}$ & $2.0 \times 10^{1} \pm 0.14^{\mathrm{b}}$ & $1.6 \times 10^{1} \pm 0.18^{\mathrm{c}}$ & $1.9 \times 10^{1} \pm 0.03^{\mathrm{b}}$ & $1.5 \times 10^{2} \pm 0.10^{\mathrm{a}}$ & $1.3 \times 10^{1} \pm 0.76^{\mathrm{d}}$ \\
$\mathrm{S}_{6}$ & $1.0 \times 10^{2} \pm 0.16^{\mathrm{ab}}$ & $0.9 \times 10^{2} \pm 0.01^{\mathrm{c}}$ & $1.2 \times 10^{2} \pm 0.04^{\mathrm{a}}$ & $1.1 \times 10^{2} \pm 0.22^{\mathrm{a}}$ & $1.8 \times 10^{1} \pm 0.14^{\mathrm{d}}$ \\
$\mathrm{S}_{7}$ & $1.9 \times 10^{1} \pm 1.02^{\mathrm{d}}$ & $1.6 \times 10^{1} \pm 0.23^{\mathrm{e}}$ & $0.5 \times 10^{2} \pm 0.91^{\mathrm{a}}$ & $2.8 \times 10^{1} \pm 0.60^{\mathrm{c}}$ & $0.4 \times 10^{2} \pm 0.19^{\mathrm{b}}$ \\
$\mathrm{S}_{8}$ & $0.7 \times 10^{2} \pm 0.06^{\mathrm{c}}$ & $0.3 \times 10^{2} \pm 0.48^{\mathrm{e}}$ & $9.8 \times 10^{1} \pm 0.70^{\mathrm{a}}$ & $0.8 \times 10^{2} \pm 0.59^{\mathrm{b}}$ & $3.5 \times 10^{1} \pm 0.13^{\mathrm{d}}$ \\
$\mathrm{S}_{9}$ & $6.5 \times 10^{1} \pm 0.05^{\mathrm{b}}$ & $3.0 \times 10^{1} \pm 0.68^{\mathrm{d}}$ & $1.0 \times 10^{2} \pm 0.16^{\mathrm{a}}$ & $1.3 \times 10^{1} \pm 0.32^{\mathrm{e}}$ & $0.5 \times 10^{2} \pm 0.34^{\mathrm{c}}$ \\
$\mathrm{S}_{10}$ & $4.3 \times 10^{1} \pm 0.50^{\mathrm{d}}$ & $0.7 \times 10^{2} \pm 0.10^{\mathrm{c}}$ & $0.8 \times 10^{2} \pm 0.05^{\mathrm{b}}$ & $1.1 \times 10^{2} \pm 0.89^{\mathrm{a}}$ & $2.4 \times 10^{1} \pm 0.51^{\mathrm{e}}$
\end{tabular}

Within rows, values followed by the same alphabets are not significantly different but those followed by different alphabets are significantly different $\left(p<0.05\right.$. Recommended Standard Counts: Aerobic bacteria count $(\mathrm{ABC})=\leq 10^{5} / \mathrm{g}$, Coliform count $(\mathrm{CC})=<100 / \mathrm{g}$, Fungal count $(\mathrm{FC})=\leq$ $10^{4} / \mathrm{g}[21 ; 22]$.

Table 3 Mean Fungal Count

\begin{tabular}{|c|c|c|c|c|c|}
\hline \multirow{2}{*}{$\begin{array}{l}\text { Suya } \\
\text { samples }\end{array}$} & \multirow[b]{2}{*}{$\begin{array}{l}\text { IMSU Junction } \\
\text { (CFU/g) }\end{array}$} & \multirow[b]{2}{*}{$\begin{array}{l}\text { Standard Shoe } \\
\text { Junction } \\
\text { (CFU/g) }\end{array}$} & \multicolumn{2}{|l|}{ Sample Locations } & \multirow[b]{2}{*}{$\begin{array}{l}\text { New Owerri - } \\
\text { Concord/ All } \\
\text { Season Hotels } \\
\text { (CFU/g) }\end{array}$} \\
\hline & & & $\begin{array}{l}\text { Control-Round- } \\
\text { About } \\
\text { (CFU/g) }\end{array}$ & $\begin{array}{l}\text { Fire Service } \\
\text { Round About } \\
\text { (CFU/g) }\end{array}$ & \\
\hline $\mathrm{S}_{1}$ & $1.4 \times 10^{2} \pm 0.18^{c}$ & $1.2 \times 10^{2} \pm 0.03^{\mathrm{cd}}$ & $2.3 \times 10^{3} \pm 0.10^{\mathrm{a}}$ & $1.0 \times 10^{2} \pm 0.03^{\mathrm{d}}$ & $0.5 \times 10^{3} \pm 0.40^{b}$ \\
\hline $\mathrm{S}_{2}$ & $0.7 \times 10^{2} \pm 0.22^{\mathrm{b}}$ & $0.4 \times 10^{2} \pm 0.09^{c}$ & $1.1 \times 10^{2} \pm 0.07^{a}$ & $0.6 \times 10^{2} \pm 0.09 \mathrm{bc}$ & $3.9 \times 10^{1} \pm 0.08^{c d}$ \\
\hline $\mathrm{S}_{3}$ & $1.0 \times 10^{3} \pm 0.05^{\mathrm{a}}$ & $0.8 \times 10^{3} \pm 0.31^{b c}$ & $0.8 \times 10^{2} \pm 0.12^{\mathrm{e}}$ & $0.9 \times 10^{3} \pm 0.31^{\mathrm{ab}}$ & $1.0 \times 10^{2} \pm 0.11^{\mathrm{d}}$ \\
\hline $\mathrm{S}_{4}$ & $0.4 \times 10^{2} \pm 0.07^{d}$ & $1.1 \times 10^{2} \pm 0.06^{\mathrm{ab}}$ & $1.0 \times 10^{2} \pm 0.06^{\mathrm{bc}}$ & $1.2 \times 10^{2} \pm 0.06^{\mathrm{a}}$ & $0.9 \times 10^{2} \pm 0.32^{c}$ \\
\hline $\mathrm{S}_{5}$ & $1.1 \times 10^{3} \pm 0.21^{\mathrm{ab}}$ & $1.0 \times 10^{3} \pm 0.12^{\mathrm{bc}}$ & $1.2 \times 10^{3} \pm 0.09^{a}$ & $0.9 \times 10^{3} \pm 0.12^{\mathrm{cd}}$ & $1.1 \times 10^{2} \pm 0.06^{\mathrm{e}}$ \\
\hline $\mathrm{S}_{6}$ & $1.5 \times 10^{2} \pm 0.72^{\mathrm{d}}$ & $2.5 \times 10^{2} \pm 0.44 \mathrm{bc}$ & $1.1 \times 10^{2} \pm 0.08^{\mathrm{e}}$ & $2.7 \times 10^{2} \pm 0.44 b$ & $0.3 \times 10^{3} \pm 0.55^{a}$ \\
\hline $\mathrm{S}_{7}$ & $1.0 \times 10^{2} \pm 0.65^{b}$ & $1.4 \times 10^{2} \pm 0.60^{\mathrm{cd}}$ & $1.3 \times 10^{3} \pm 0.14^{\mathrm{a}}$ & $1.2 \times 10^{2} \pm 0.60^{d}$ & $1.5 \times 10^{2} \pm 0.78^{e}$ \\
\hline $\mathrm{S}_{8}$ & $9.7 \times 10^{2} \pm 0.19 a$ & $0.5 \times 10^{3} \pm 0.56^{c}$ & $2.8 \times 10^{2} \pm 0.16^{\mathrm{d}}$ & $0.7 \times 10^{3} \pm 0.56^{b}$ & $2.3 \times 10^{2} \pm 0.22 \mathrm{e}$ \\
\hline $\mathrm{S}_{9}$ & $1.4 \times 10^{2} \pm 0.15^{\mathrm{d}}$ & $2.6 \times 10^{2} \pm 0.18^{c}$ & $1.0 \times 10^{3} \pm 0.36^{\mathrm{a}}$ & $2.8 \times 10^{2} \pm 0.18^{\mathrm{bc}}$ & $2.9 \times 10^{2} \pm 0.45^{b}$ \\
\hline $\mathrm{S}_{10}$ & $1.0 \times 10^{3} \pm 0.09^{\mathrm{ab}}$ & $0.9 \times 10^{3} \pm 0.10^{b c}$ & $1.1 \times 10^{3} \pm 0.29^{a}$ & $1.0 \times 10^{3} \pm 0.10^{\mathrm{ab}}$ & $8.0 \times 10^{2} \pm 0.19^{c}$ \\
\hline
\end{tabular}

Within rows, values followed by the same alphabets are not significantly different but those followed by different alphabets are significantly different $(\mathrm{p}<0.05)$. Recommended Standard Counts: Aerobic bacteria count $(\mathrm{ABC})=\leq 10^{5} / \mathrm{g}$, Coliform count $(\mathrm{CC})=<100 / \mathrm{g}$, Fungal count $(\mathrm{FC})=\leq$ $10^{4} / \mathrm{g}[21 ; 22]$. 


\section{Discussion}

The high protein content of meat [23] which transforms into high nutrient and moisture content makes meat prone to bacterial invasion and fungal growth [23; 24]. Based on this, meat should be properly handled to avoid bacterial or fungal contamination. Microbial contaminations lead to meat spoilage and all sorts of food-borne diseases. This affects the microbial quality of the processed suya for consumption.

In this study, microbial counts were on the high thresholds although they were within microbiological acceptable limits recommended by regulatory bodies for vended meat and meat products [21; 22]. According to [23], retailed meat and meat products are normally sold in markets in unhygienic conditions, most often in open tables. Suya is not left out in the trend as they are most often seen vended in open trays or wheelbarrows along the streets, around crowded places like motor parks, displayed as ready for sale in open tables and in open grill stands in highly polluted areas, thereby exposing the products to harmful environmental elements. These are various sources of contamination that attested to the results of high microbial counts recorded in the study. The microbial counts in the results would have been more than the recorded if not for the vegetable oil used during the processing, which is added at intervals during waiting periods to keep it fresh before customers. Oil is used in preserving food, meat and other edible items because of its negative tendencies in supporting microbial growth especially the aerobes by sealing up the air pores within and thereby creating anaerobic conditions [25].

These recorded high heterotrophic, coliform and fungal counts are indicative of contamination. Most of the contaminations according to [23] are encountered during the various stages of slaughtering from inherent intestine, prevailing environment, transportation and handling/ processing. A total of seven (7) bacterial and three (3) fungal genera were isolated and identified to include: Bacillus species, Escherichia coli, Salmonella species, Staphylococcus aureus, Shigella species, Klebsiella species, Pseudomonas species; and Candida albicans, Penicillium species, Aspergillus species respectively. This result was similar to the findings of $[4 ; 7 ; 8 ; 23 ; 26]$. Also, the isolated genera in the result were in agreement with the report of [27] which stated that microbiological analysis of meat samples in Awka Urban of Anambra State, indicated contamination of meat samples with various bacterial species including Staphylococcus aureus, and some enteric bacteria.

The presence of coliform in the suya samples and other bacteria such as Bacillus species in food has been described as index of food hygiene [13; 28]. Escherichia coli, Salmonella species, Shigella species and Klebsiella species are found in the intestinal tracts of livestock, poultry, dogs, cats, and other warm-blooded animals as normal flora. The presence of these organisms as they belong to the family of Enterobacteriaceae and are closely related genetically, depicts feacal contamination of the suya samples which could be traced to poor personal hygiene and contaminated water. This is evident because $E$. coli is an indicator organism for feacal contamination and that makes the contaminated suya unfit for consumption because E. coli can cause gastroenteritis. According to [25; 29], the presence of Staphylococcus aureus depicts contamination from human handling, since Staphylococcus aureus is a normal flora of human skin and nose. Consumption of Staphylococcus aureus infected food can lead to bacteremia, endocarditis etc. The presence of Pseudomonas species points to contamination from either soil and/or water. In [25], they classified them as environmental contaminants while considering exposure rates of some locally made snacks by vendors/hawkers. Likewise, Pseudomonas species could contaminate suya from environmental elements such as soil, water, air, dust particles etc.

Due to the high moisture content of meat as was reported by [24] which is directly related to water activity ( $\mathrm{a}_{\mathrm{w}}$ ), growth of fungi on meat is inevitable as it is greatly encouraged. When there is left over after sales, and because chemical preservatives were not used during processing, then fungal growth is encouraged considering the poor storage conditions.

\section{Conclusion}

From the results, it is clearly established that handling and processing activities of suya in Owerri metropolis were poor and below acceptable hygiene standards. This is evidenced in the high microbial counts recorded in the study. The locations and beehive of activities around the area and personal hygiene of the processors/ vendors play a major contributory factor to the obtained results. In order to achieve a sustainable food safety quality for vended suya across the different locations in Owerri metropolis, there is need for education and awareness campaigns for processors, vendors and consumers on the role of personal hygiene in food safety and the imminent risk of consuming contaminated suya. 


\section{Compliance with ethical standards}

\section{Acknowledgments}

Authors are grateful to every contributor.

Disclosure of conflict of interest

No conflict of interest.

\section{References}

[1] Komba EVG, Komba EM, Mkupasi AO, Mbyuzi S, Mshamu D, Luwumbra Z, Busagwe and Mzula A. (2012). Sanitary practices and occurrence of zoonotic conditions in cattle at slaughter in Morogoro Municipality, Tanzania: Implications for public health. Tanzania Journal Health Research, 14(2), 131-138.

[2] Mayr D, Margesin R, Klingsbichel E, Hartungen E, Jenewein D, Schinner F and Mark TD. (2010). Rapid detection of meat spoilage by measuring volatile organic compounds by using proton transfer reaction mass spectrometry. Journal of Applied Environmental Microbiology, 69, 4697-4705.

[3] EL Hassan FI, Umar SF, Yahaya A and Ali M. (2018). Microbial quality assessment of processed meat product (Tsire) sold within Wudil town, Wudil Local Government Area, Kano State, Nigeria. Modern Applications in Pharmacy and Pharmacology, 2(2), 1-7.

[4] Falegan CR, Akoja SO and Oyarekua MA. (2017). Microbiological assessment of suya (sliced roasted beef) in AdoEkiti Metropolis, Ekiti State, Nigeria. MOJ Biology and Medicine, 2(3), 266-269.

[5] Alonge DO and Hiko AA. (1981).Traditional methods of meat preservation in Nigeria. West African Farm Food Processings, 19-21.

[6] Abdullahi I, Umoh V, Ameh J and Galadima M. (2004). Hazards associated with Kilishi preparation in Zaria, Nigeria.Nigerian Journal of Microbiology, 18(1-2), 339 - 345.

[7] Inyang C, Igyor M and Uma E. (2005). Bacterial Quality of a Smoked Meat product ('Suya'). Nigeria Food Journal, $23,239-242$.

[8] Edema MO, Osho AT and Diala CI. (2008). Evaluation of microbial hazards associated with the processing of suya (a grilled meat product). Scientific Research and Essay, 3(12), 621-626.

[9] Igene J0 and Mohammed ID. (1983). Consumers' preferences and attitudes to suya. An indigenous Nigerian meat product. Annals of Borno, 1, 169-176.

[10] Vilar I, García-Fontan MC, Prieto B, Tornadizo ME and Carballo J. (2000). A survey on the microbiological changes during the manufacture of dry-cured lacon, a Spanish traditional meat product. Journal of Applied Microbiology, $89,1018-1026$.

[11] Buchanan RL and Whiting RC. (1986). Processed meats as a Arrhenius model and the square root model for predicting microbial environment. Food Technology, 40, 134-138.

[12] Ercolini DF, Russo E, Torrieri P, Masi and Villani F. (2006). Changes in the spoilage-related microbiota of beef during refrigerated storage under different packaging conditions. Journal of Applied and Environmental Microbiology, 72(7), 4663-4671.

[13] Jay MJ, Loessner MJ and Golden DA. (2005). Modern Food Microbiology, Seventh Edition. Springer Publishers, USA, 41.

[14] Whyte P, McGill K, Cowley D, Madden RH, Moran L, Scates P, Carroll C, O'Leary A, Fanning S, Collins JD, McNamara E, Moore JE and Cormican M. (2004). Occurrence of Campylobacter in retail foods in Ireland. International Journal of Food Microbiology, 95, 111-118.

[15] Odusote K and Akinyanju 0. (2003). Red suya syndrome. Acute intravascular administration and control. Consumer safety bulletin, 2(2), 20-24.

[16] Rahmann MS, Salman Z, Kadim IT, Mothershaw A, Al Riziqi MH, Guizani N. Mahgoub O and Ali A. (2005). Microbial and physico-chemical characteristics of dried meat processed by different methods. International Journal of Food Engineering, 1(2), 1-14. 
[17] Okonkwo T. (1987). About Suya and Yaji. Journal of. Food and Agriculture, 1(1), 51.

[18] Cappucino GJR and Sherman B. (2010). Microbiology: A Laboratory Manual, 9th Edition. The Benjamin Publishing Company. California.

[19] Boone DR, Castenholz RW, Garrity GM, Brenner DJ, Krieg NR and Staley JR. (Eds.). (2005). Bergey's Manual of Systematic Bacteriology. Second Edition. New York: SpringerVerlag.

[20] Kidd S, Halliday C, Alexiou H and Ellis D. (2016). Description of Medical Fungi. 3rd Edition. Newstlye Printing. Adelaide, South Australia 5031, Australia, 23-170.

[21] Food Standards Australia New Zealand - FSANZ. (2018). Compendium of Microbiological Criteria for Food.

[22] Public Health Laboratory Service - PHLS. (2000). Guidelines for the microbiological quality of some ready-to-eat foods sampled at the point of sale. Communicable Disease \& Public Health, 3, 163-7.

[23] Ike CC and Akortha EE. (2017). Microbial diversity associated with different fresh meats sold in Aba metropolis, Abia State, Nigeria. International Journal of Research and Development Organization (IJRDO) - Journal of Biological Science, 3(5), 108-121.

[24] Emeka-Ike PC, Ebiringa DC, Ike CC, Nwogu OG and Akwari DK. (2018). Effect of boiling time on the proximate composition and microbiological quality of various parts of cattle meat. International Journal of Innovative Science, Engineering and Technology, 5(9), 47-63.

[25] Ike CC, Emeka-Ike PC, Nwokorie CC and Anochie CC. (2015). Microbiological quality evaluation of locally prepared snacks sold in Aba metropolis, Abia State, Nigeria. International Journal of Scientific Engineering and Applied Science (IJSEAS),1(7), 46-59.

[26] Alonge, 00, Wakkala FI, Ogbaga CC and Akindele KA. (2017). Bacterial analysis of barbecued meat (suya) from selected locations within Abuja, Nigeria. International Conference on Electronics, Computer and Computation (ICECCO), 13, 1-5.

[27] Chukwura E and Mojekwu C. (2002). Prevalence of microbial contaminants of suya meat sold in Awka Urban. Journal of Tropical Microbiology, 11, 89-91.

[28] Adesokan I, Odotoyinbo B and Olubamiwa A. (2008). Statistical optimization of lactic acid production by lactococcuslastis strain, using the central composite experimental design. African Journal of Biotechnology, $7(20), 3799-3805$.

[29] Ike CC, Emeka-Ike PC and Akortha EE. (2017). Microbial evaluation of tigernut (Cyperus esculentus L.) sold in Aba, Abia State, Nigeria. International Journal of Research and Development Organization (IJRDO) - Journal of Biological Science, 3(5), 97-107. 